\title{
Pemberdayaan kelompok Nasyiatul 'Aisyiyah cabang Moyudan dan Seyegan dalam program anti hoax terkait makanan dan minuman di media sosial elektronik
}

\author{
Titin Aryani ${ }^{1 *}$, Dwi Ernawati ${ }^{2}$ \\ 1,2 Fakultas Ilmu Kesehatan Universitas ‘Aisyiyah Yogyakarta
}

\section{INFORMASI ARTIKEL:}

\section{Riwayat Artikel:}

Tanggal diterima: 25 Juni 2021

Tanggal direvisi: 20 Juni 2021

Tanggal dipublikasi: 30 Juni 2021

Kata kunci:

Nasyiatul 'Aisyiyah

Moyudan

Anti hoak

Makanan

Key word:

Nasyiatul 'Aisyiyah

Moyudan

Anti hock

Food

\begin{abstract}
ABSTRAK
Latar Belakang: Survei yang dilakukan oleh Asosiasi Penyelenggara Jaringan Internet Indonesia (APJII) mengungkap bahwa lebih dari setengah penduduk Indonesia kini telah terhubung ke internet. Usia 10-34 tahun adalah kelompok yang paling dominan dalam menggunakan internet. Data tersebut menyiratkan pengguna internet diisi oleh usia produktif, seperti halnya pada kelompok Nasyiatul 'Aisyiyah (NA) Cabang Moyudan dan Seyegan. Tujuan: pemberdayaan kelompok NA cabang Moyodan dalam rangka mengantisipasi berita Hoax khususnya yang terkait dengan makanan dan minuman. Permasalahan Mitra: Mitra berusia produktif dan dominan menggunakan internet, sehingga rentan terhadap berita hoax, khususnya terkait makanan dan minuman, Mitra memerlukan pengetahuan tentang karakteristik makanan dan minuman yang sehat dan bergizi, dan Mitra memerlukan pendampingan dan lokakarya dalam implementasi gerakan anti hoax, khususnya terkait makanan dan minuman. Solusi yang ditawarkan: Edukasi tentang karakteristik berita hoax, khususnya terkait makanan dan minuman, pelatihan identifikasi berita hoax, khususnya terkait makanan dan minuman, dan pembentukan agen anti hoax. Metode Pelaksanaan: Koordinasi dengan mitra, edukasi dan pelatihan program anti hoak dan pemberdayaan mitra sebagai agen anti hoak. Target Luaran: Peningkatan pengetahuan dan keterampilan tentang identifikasi berita hoax, khususnya terkait makanan dan minuman, terbentuknya agen anti hoax sebagai langkah kaderisasi anti hoax makanan dan minuman, publikasi ilmiah di media sosial, HaKI, dan publikasi di jurnal pengabdian masyarakat. Simpulan: kegiatan PkM di dapatkan hasil bahwa pengetahuan peserta PkM terkait antihoax makanan dan minuman dimedia sosial mengalami peningkatan dan telah terbentuk agen anti hoax makanan dan minuman di Ranting Nasyiatul ‘Aisyiyah Moyudan dan Sayegan.
\end{abstract}

Background: A survey conducted by the Association of Indonesian Internet Network Providers revealed that more than half of Indonesia's population is now connected to the internet. Ages 10-34 years are the most dominant group in using the internet. The data implies that internet users are used by productive age community, and those who join Nasyiatul 'Aisyiyah (NA) Moyudan and Seyegan Branches are also included. Objective: The objective of the community service is to empower NA group members of Moyodan branch in anticipating hoax news, especially those related to food and beverages. Partner Problems: Partners are productive age and dominantly use the internet, so they are vulnerable to hoax news, especially related to food and beverages. Partners need knowledge about the characteristics of healthy and nutritious food and beverages, and partners need assistance and workshops in the implementation of the anti-hoax movement, especially related to food and Drink. Solutions offered: Education about the characteristics of hoax news, particularly related to food and beverages, training on the identification of hoax news, especially related to food and beverages, and the establishment of anti-hoax agents were provided. Implementation Method: The methods covered coordination with partners, education and training on anti-hoax programs and empowerment of partners as anti-hoax agents. Outcome Targets: The expected income included the increase knowledge and skills regarding the identification of hoax news, especially related to food and beverages, the formation of anti-hoax agents as a step to cadre anti-hoax food and beverages, scientific publications on social media, Intellectual Property Rights, and publications in community service journals. Conclusion: The community service activities showed that the knowledge of the participants related to anti-hoax food and beverages on social media had increased, and an anti-hoax agent for food and beverages was formed in the Nasyiatul 'Aisyiyah Moyudan and Sayegan Branches. 


\section{Pendahuluan}

Beberapa tahun ini, berita Hoax memang makin cukup meresahkan orang banyak, termasuk warga Moyudan Sleman. Hoax yang menyebar pada umumnya berkaitan dengan sosial politik, keagamanaa, kesehatan dan makanan dan minuman. Fenomena ini menggiring masyarakat dengan terpaan beragam informasi tanpa literasi budaya baca tulis yang kuat dari konten media sosial.Penyebaran informasi yang cepat tanpa mengindahkan etika pemberitaan dalam media online membuat pembaca sulit membedakan mana informasi yang benar dan mana yang dipalsukan di facebook, whatsApp,Line, dan informasi pesan instan sangat massif untuk penyebaran informasi berita bohong atau hoax (Majid, 2019).

Makanan dan minuman memiliki peran penting bagi kehidupan manusia, sejumlah oknum pun menjadikannya sebagai objek hoaks. Hal ini tentu akan menimbulkan kekhawatiran di tengah masyarkat. Berita bohong atau hoaks di bidang makanan dan minuman menempati urutan ketiga hoaks yang paling banyak beredar di masyarakat, menurut data Masyarakat Anti Fitnah Indonesia (Mafindo). Hoaks tersebut disebarkan oleh orangorang baik disengaja maupun tanpa sengaja. Mereka menganggap informasi tersebut harus segera disampaikan karena berguna bagi orang lain (Ramadhan, 2017). Kondisi ini menjadi salah satu alasan cepatnya penyebaran hoaks melalui media sosial.

Perusahaan media asal Inggris yang bekerja sama dengan Hootsuite, melakukan penelitian tentang penggunaan media sosial di Indonesia pada tahun 2018. Hasilnya menunjukkan bahwa orang Indonesia mengakses media sosial selama lebih dari 3 jam setiap harinya. Indonesia memiliki total populasi sebanyak 265,4 juta jiwa, sementara pengguna media sosial adalah 130 juta pengguna. Data ini menunjukkan bahwa penetrasi media sosial mencapai 49 persen (Pertiwi, 2018, h. 1). Sementara itu, penelitian Mastel tentang hoaks (Mastel, 2017, h. 17) menyimpulkan bahwa Facebook, Twitter, Instagram, dan Path adalah media sosial yang paling sering digunakan untuk menyebarkan hoaks dengan jumlah pengguna 92,4 persen, disusul oleh aplikasi chatting, seperti
Whatsapp, Line, dan Telegram, sebanyak 62,8 persen, dan melaluisitus web sebanyak 34,9 persen.

Survei yang dilakukan oleh Asosiasi Penyelenggara Jaringan Internet Indonesia (APIII) mengungkap bahwa lebih dari setengah penduduk Indonesia kini telah terhubung ke internet. Terdata bahwa 132,7 juta orang dari 256,2 juta orang penduduk Indonesia telah terhubung ke internet. Data lain menunjukkan usia 10-34 tahun adalah kelompok yang paling dominan dalam menggunakan internet. Data tersebut menyiratkan pengguna internet diisi oleh usia produktif, seperti halnya pada kelompok Nasyiatul 'Aisyiyah (NA) Cabang Moyudan dan Seyegan. Kondisi ini menarik perhatian tim pengusul pengabdian kepada masyarakat Universitas 'Aiysiyah Yogyakarta untuk memberikan edukasi dan pemberdayaan kelompok NA cabang Moyodan dan Seyegan dalam rangka mengantisipasi berita Hoax khususnya yang terkait dengan makanan dan minuman.

\section{Metode Pelaksanaan}

a. Koordinasi dan sosialisasi program dengan Nasyiatul Aisyiyah Cabang Moyudan dan Seyegan

Dalam memulai serangkaian kegiatan pengabdian, tim pelaksana pengabdian masyarakat berkoordinasi dengan pimpinan cabang Nasyiatul Aisyiyah Moyudan dan Seyegan berkaitan dengan kegiatan pengenalan dan pelatihan, terutama mengenai metode pelaksanaan kegiatan dan jadwal pelaksanaan. cabang Nasyiatul Aisyiyah Moyudan dan Seyegan diharapkan dapat membantu tim pengabdian dalam mendukung pelaksanaan kegiatan pelatihan. pimpinan cabang Nasyiatul Aisyiyah Moyudan dan Seyegan diharapkan dapat menginstruksikan kepada anggotanya untuk dapat menjadi peserta aktif dan mengikuti serangkaian kegiatan pelatihan tersebut. Jumlah peserta yang diharapkan dapat mengikuti kegiatan tersebut berjumlah 25 orang. Kegiatan ini akan menjadi tanggungjawab ketua dan anggota pelaksana dibantu oleh 4 orang mahasiwa. Mitra bertugas mengkoordinir peserta pelatihan melalui media online. Setelah kegiatan koordinasi, dilakukan juga sosialisasi

*Korespondensi penulis.

Alamat E-mail: titin.aryani@unisayogya.ac.id 
program oleh pelaksana pengabdian masyarakat terhadap mitra.

b. Edukasi dan pelatihan tentang identifikasi makanan dan minuman sehat berdasarkan karakter fisik makanan dan minuman.

Berdasarkan permasalahan di atas maka dalam kegiatan ini akan diawali dengan pemahaman pengetahuan kelompok cabang Nasyiatul Aisyiyah Moyudan dan Seyegan terkait identifikasi makanan dan minuman sehat berdasarkan karakter fisik makanan dan minuman. Hal ini dilakukan karena kurangnya pengetahuan warga terkait hal tersebut. Kegiatan ini menjadi tanggung jawab ketua pelaksana dibantu oleh seorang anggota pelaksana dan 4 orang mahasiswa. Narasumber edukasi adalah ketua pelaksana. Mitra bertanggungjawab mempersiapkan peserta edukasi dan kehadiran peserta dalam pelatihan online melalui grup Whatshapp dan Youtube.

c. Pelatihan identifikasi berita hoax, khususnya terkait makanan dan minuman

Pelatihan identifikasi berita hoax, khususnya terkait makanan dan minuman dapat dilakukan dengan cara menyaring berita hoax yang telah diterima dan menganalisis berita hoax tersebut dengan pemikiran yang kritis. Dalam pelatihan ini, peserka akan diberikan pengetahuan mengenai cara menyaring berita hoax tentang makanan dan minuman serta diberikan contoh tentang berita hoax dan bagaimana menganalisis dan menelusuri berita tersebut sehingga dapat diketahu bahwa berita tersebut adalah hoax. Kegiatan ini rencananya akan dilakukan pada bulan Januari 2021. Kegiatan ini menjadi tanggungjawab tim pelaksana. Narasumber pelatihan adalah ketua pelaksana. Mitra bertanggungjawab mempersiapkan peserta edukasi dan dan kehadiran peserta dalam pelatihan online melalui grup Whatshapp dan Youtube.

d. Pembentukan Agen Anti Hoax terkait Makanan dan Minuman

Pembentukan agen hoax dilakukan dengan cara menyaring nilai pre test dan post test pada kegiatan pelatihan. Dari 25 peserta pelatihan akan dipilih 4 orang dengan nilai tertinggi untuk menjadi agen anti hoax dan dilakukan pendampingan khusus dan pemantauan oleh tim pelaksana pengabdian agar dapat melaksanakan program anti hoax terkait makanan dan minuman dengan baik. Kegiatan ini rencananya akan dilakukan pada bulan
Januari 2021 dan agen anti hoax akan diumumkan setelah pelatihan. Kegiatan ini menjadi tanggungjawab tim pelaksana. Narasumber pelatihan adalah ketua pelaksana. Mitra bertanggungjawab mempersiapkan peserta edukasi dan dan kehadiran peserta dalam pelatihan online melalui grup Whatshapp dan Youtube.

e. Monitoring dan Evaluasi

f. Monitoring dan evaluasi kegiatan dilakukan setelah 1 bulan pasca pelaksanaan program kegiatan IbM. Metode monitoring dilakukan dengan cara melakukan evaluasi dan diskusi terkait tantangan dan hambatan yang dialami oleh mitra dalam implementasi kegiatan program anti hoax terkait makanan dan minuman tersebut

\section{Hasil dan Pembahasan}

Pelaksanaan kegiatan pengabdian masyakarat ini dilakukan dengan beberapa tahapan yaitu sebagai berikut ;

\begin{tabular}{|c|c|c|c|}
\hline No & Nama Kegiatan & $\begin{array}{l}\text { Partisipasi } \\
\text { mitra }\end{array}$ & $\begin{array}{l}\text { Evaluasi dan } \\
\text { keberlanjutan } \\
\text { program }\end{array}$ \\
\hline 1 & \begin{tabular}{|l|} 
Koordinasi dan \\
sosialisasi \\
program dengan \\
Nasyiatul Aisyiyah \\
Cabang Moyudan \\
dan Seyegan \\
\end{tabular} & $\begin{array}{l}\text { Melakukan } \\
\text { koordinasi } \\
\text { dengan tim } \\
\text { pengabdian } \\
\text { masyarakat }\end{array}$ & $\begin{array}{l}\text { Tersusunnya rencana } \\
\text { kegiatan }\end{array}$ \\
\hline 2 & $\begin{array}{l}\text { Edukasi dan } \\
\text { pelatihan tentang } \\
\text { identifikasi } \\
\text { makanan dan } \\
\text { minuman sehat } \\
\text { berdasarkan } \\
\text { karakter fisik } \\
\text { makanan dan } \\
\text { minuman }\end{array}$ & $\begin{array}{l}\text { Mengikuti } \\
\text { pelatihan } \\
\text { tentang } \\
\text { identifikasi } \\
\text { makanan dan } \\
\text { minuman } \\
\text { sehat } \\
\text { berdasarkan } \\
\text { karakter fisik } \\
\text { makanan dan } \\
\text { minuman } \\
\end{array}$ & $\begin{array}{l}\text { Terlaksananya pelatihan } \\
\text { tentang identifikasi } \\
\text { makanan dan minuman } \\
\text { sehat berdasarkan karakter } \\
\text { fisik makanan dan } \\
\text { minuman }\end{array}$ \\
\hline 3 & $\begin{array}{l}\text { Pelatihan } \\
\text { identifikasi berita } \\
\text { hoax, khususnya } \\
\text { terkait makanan } \\
\text { dan minuman }\end{array}$ & \begin{tabular}{|l|} 
Mengikuti \\
pelatihan \\
identifikasi \\
berita hoax, \\
khususnya \\
terkait \\
makanan dan \\
minuman
\end{tabular} & $\begin{array}{l}\text { Terlaksananya pelatihan } \\
\text { identifikasi berita hoax, } \\
\text { khususnya terkait makanan } \\
\text { dan minuman }\end{array}$ \\
\hline 4 & $\begin{array}{l}\text { Pembentukan } \\
\text { Agen Anti Hoax } \\
\text { terkait Makanan } \\
\text { dan Minuman }\end{array}$ & $\begin{array}{l}\text { Pembentukan } \\
\text { agen anti hoax } \\
\text { terkait } \\
\text { makanan dan } \\
\text { minuman } \\
\end{array}$ & $\begin{array}{l}\text { Terbentuknya agen anti } \\
\text { hoax }\end{array}$ \\
\hline 5 & $\begin{array}{l}\text { Monitoring dan } \\
\text { Evaluasi }\end{array}$ & \begin{tabular}{|l|} 
Melakukan \\
evaluasi agen \\
anti hoax yang \\
terbentuk
\end{tabular} & Evaluasi \\
\hline
\end{tabular}

Tabel 1 Kegiatan Pengabdian Kepada Masyarakat 


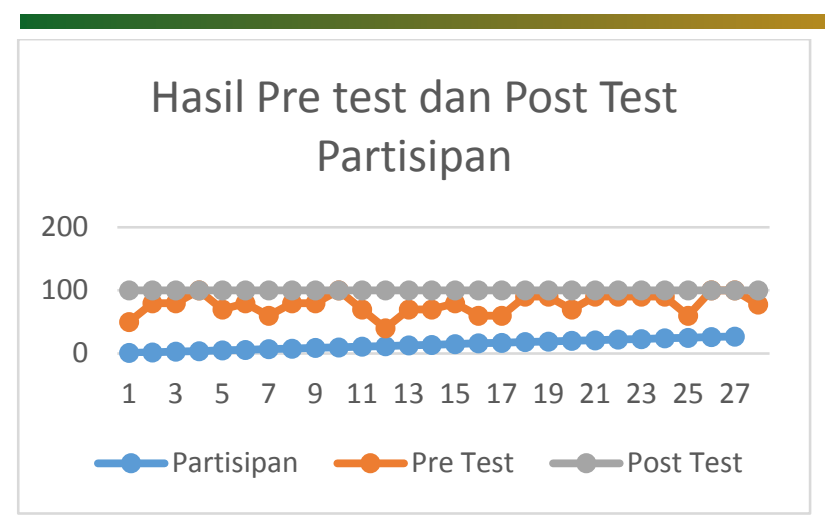

Gambar 1. Hasil Kegiatan Pengabdian Kepada Masyarakat

Peserta kegiatan program antihoax makanan dan minuman berjumlah 27 orang. Kegiatan dilaksanakan pada tanggal 30 Maret 2021. Berdasarkan Gambar 1 diketahui bahwa terjadi peningkatan pengetahuan dan keterampilan peserta dengan nilai nilai rata-rata pre test peserta sebelum pelatihan adalah 78 dan nilai post test setelah pelatihan adalah 100 .

Pengabdian kepada masyarakat berupa pemberian informasi dengan memberikan penyuluhan atau media interaktif seperti video akan meningkatkan pengetahuan dari masyarakat. Hal ini sesuai dengan Machfoedz (2005) bahwa pemberian pendidikan kesehatan melalui media akan mempermudah penerimaan informasi dari sasaran.

\section{Simpulan}

Berdasarkan kegiatan yang telah dilaksanakan mulai dari persiapan sampai dengan pelaksanaan dapat disimpulkan bahwa pelaksanaan PPM telah dilakukan meliputi rekrutmen calon peserta PPM, persiapan median PPM, pelaksanan dan evaluasi kegiatan PPM. Dari hasil kegiatan PPM di dapatkan hasil bahwa pengetahuan peserta PPM terkait antihoax makanan dan minuman dimedia sosial mengalami peningkatan dan telah terbentuk agen anti hoax makanan dan minuman di Ranting Nasyiatul 'Aisyiyah Moyudan dan Sayegan. Saran untuk kegiatan PPM kedepan, diharapkan ada pelatihan untuk menganalisi makanan yang mengandung bahan pengawet atau tidak dengan metode sederhana.

\section{Ucapan terima kasih}

Seluruh TIM PPM mengucapkan terimakasih kepada Universitas 'Aisyiyah Yogyakarta yang telah mendanai kegiatan Pengabdian kepada Masyarakat ini pada skema Hibah Pengabdian Internal Universitas 'Aisyiyah Yogyakarta.

\section{Daftar Pustaka}

BPOM. 2011. Pentingnya promosi keamanan pangan di sekilah untuk menyelamatkan generasi penerus. Buletin Vol.12 no.6 November-Desember.

Majid, A. 2019. Fenomena penyebaran hoax dan literasi bermedia sosial lembaga mahasiswa universitas muslim indonesia. Jurnal Komodifikasi, Volume 8, Desember 2019, hal 228-239.

Machfoedz, Irkham \& Suryani, Eko. 2005. Pendidikan kesehatan Bagian dari Promosi Kesehatan. Yogyakarta: Fitramaya 